\title{
FINANCIAL IMPACT IN CASE OF INVESTMENT TO THE FOREST PROPERTY AS A RESULT OF DIFFERENT TREE SPECIES COMPOSITION IN THE CZECH REPUBLIC
}

\author{
Pavlína Köhler, Vlastimil Vala
}

\section{Introduction}

The total area of forestland in the Czech Republic is about 2,593,923 ha, of which state owns $60.32 \%, 19.44 \%$ is owned by natural person, and $16.39 \%$ is owned by municipalities and the rest is owned by others legal bodies. [11]

The spruce covers the largest area $1,138,424$ ha $(47.7 \%)$; the second largest area is covered by pine - 332,685 ha $(13.9 \%)$. Coniferous species cover in total $67.2 \%$. Oak and beech - among the broadleaved species cover the largest area (7.4\%) and (7.2\%), respectively. Important species is also birch, a pioneer species (4.2\%). Broadleaved species cover in total $32.8 \%$ of the area covered by tree species. [13]

The primacy of spruce is given both by natural conditions and by the history of forest management. "According to the analysis, the current proportion of homogeneous spruce forests in the total forest area is $20.3 \%$ (pure) and the current share of spruce-dominated forest ecosystems is $10.7 \%$ (dominant)" [10, p. 521].

"In the Czech Republic, the area of the coniferous trees is about 330,000 ha larger than is appropriate for the prescribed target tree species composition, and this area should be replaced by beech" [18, p. 33]. Decrease of Abies alba from natural $20 \%$ to critical value of less than $1 \%$ leads to disappearing of $A$. alba from Czech forests [6]. Ministry of agriculture wrote in the Report about condition of Czech forests from 2010 that natural representation of spruce was $11.2 \%$, fir even $19.8 \%$ and beech $40.2 \%$ with current representation only $7.32 \%$ [12].
Additive trees grow in current spruce monocultures, which at least partly limit negative influence of spruce stands. Emission of these trees and their support possibly lowers costs on modification of species composition it the future. [16, p. 24] Frequent calamities are caused by instability of often monocultural or damaged and weakened forests whether because of their inappropriate tree composition. This is the reason for changing their current composition to their natural state.

Many scientists proved bad health condition of Czech forests and their weak resistance against biotical and abiotical factors. E.g. 31\% of Czech forests are potentially endangered by honey fungus (Armillaria sp.). It has optimum from 2 to $4 \mathrm{fvz}$ - forest vegetation zone in nutrient stations [8]. Čermák et al. [2] confirmed middle to high risk of Armillaria attacks in spruce stands within investigated locality in 3 rd and $4^{\text {th }} \mathrm{fzv}$ and its possible deterioration simultaneously with change of external conditions.

Representation of Fagus sylvatica in the Czech forests is small, even though F. sylvatica is our one of the most important forest trees. However, less attention to its health condition is paid. Beech was and is considered as relatively healthy and resistant tree, but in last years it became endangered by bark necrosis. [7]

Change of tree composition to its natural form is supported by state. It creates tools which motivate forest management to change it according to target composition and stand conditions. Subsidies are one of the tools. They buffer part of planting costs and maintenance of ameliorating species (MZD). Bartoš et al. [1] wrote that forest regeneration with high representation 
of MZD (spruce 30, oak 30, beech 30, larch 10) was supported by financial endowment, which was about 46 thousands CZK higher than real plantation costs. This difference is five times higher than in case of forest regeneration without MZD (spruce 40, beech 30, fir 30) in minimal quantity per hectare for principal tree species.

Forest owners and managers are motivated to change their forest composition. But the change will have an economic impact on their property. Bartoš et al. calculated average price of spruce and beech assortments in real stands $1,273 \mathrm{CZK} / \mathrm{m}^{3}$ spruce and $1,238 \mathrm{CZK} / \mathrm{m}^{3}$ beech. They measured $520 \mathrm{~m}^{3} / \mathrm{ha}$ in spruce stand in age of 45 years, which could correspond to site index +1 (36). [1]

Current average price of standing stale spruce wood without sorting was $1,300 \mathrm{CZK} / \mathrm{m}^{3}$ (according to private information from the harvest cut in years 2011/12).

Suitable mixture of spruce with beech has a deciding factor on production and could change according to locality. Volume and quality yield of mixed spruce-beech stand does not reach yield of pure spruce stand, but not higher than sum of yields of pure beech and pure spruce stands calculated from assistant stands. [Wiedemann 1942 ex 15].

\section{Aim and Hypotheses}

The aim of this research is to create a model of dependency of total profit from forest stand depending on its composition and prove that if the forest composition is changed in favour of beech, the financial impact will be significantly negative. For our example pure Norway spruce (SM) stand is progressively changed to pure beech $(\mathrm{BK})$ stand in $4^{\text {th }} \mathrm{fvz}$ with different site indexes. Time factor is eliminated, because all forest management activities are made at the same time in a model stand. The stand area is 100 hectares and on each hectare there is a forest group of differing age differs about 1 year from the forest besides. In one year trees are harvested, planted, maintained, protected, etc. All cash flows are related to the area of 100 ha, but all activities are done within one year. So, the results could be understood differently. The costs, revenues and profit are cash flows of 1 ha stand during 100 years.
The research is based on the three following hypotheses:

a) The model pure $S M$ stands profit more $\left(P_{a}\right)$ than pure $\mathrm{BK}$ stands $\left(\mathrm{P}_{\mathrm{b}}\right)$.

$$
\begin{aligned}
& P_{a}>P_{b} \quad P \text { - profit } \\
& P_{a}=R_{a}-C_{a} \quad C \text { - costs } \\
& P_{b}=R_{b}-C_{b} \quad R-\text { revenues. }
\end{aligned}
$$

b) Decreasing of SM composition decreases revenues and silvicultural costs rises up and total profit decreases too.

$P_{a}=P_{b} k \quad k-$ coefficient
includes influence of stand composition to the total profit.

c) The total profit is influenced by change of stand composition. The total profit (loss) is function of stand composition change.

$$
P=f(X) \quad X \text { - share spruce. }
$$

The results could be a start point for further research by modelling risks or others influences. Risk is related to possible insurance of forest, etc.

\section{Material and Methodology}

Many scientists proved that progress of high growth of dominated and co-dominated species in mixed stands is the same as high growth in pure stands. Type of mixture does not influent shape of growth curves. [Weidemann1951, Weck 1955, Halaj 1968, Hladík 1978, ex 9]. Halaj based on own research stated, that forest site type trees mixed in one stand have in average comparable site index [5].

Taking the facts above into consideration a model stand was created. The stand area is 100 ha with rotation period of 100 years and it is located in 4 th $\mathrm{fvz}$ natural beech wood stands according to the Typological classification system of ÚHÚL (The Forest Management Institute) [14]. The stand consists imaginarily of one hundred forest groups each with an area of 1 ha and different age from 1-100 years. In the whole area there will be imaginarily grown Norway spruce (SM) and all costs and revenues will be calculated within one year in the stand. In each next example it will be replaced $10 \%$ of SM by beech and continued until the stand is pure beech (BK). This presumption that was introduced above is that SM and BK on the same locality will get identical mean high in the same age meaning site index of both the trees will be the same. Regeneration period is one year. Forest regeneration will be done immediately after major harvest. The model is 
used for all site indexes. Totally there are 121 different situations. For each from eleven different site indexes from +1 (36) to 9- (16) there are eleven possible species compositions from pure spruce to pure beech stand.

No calamities or other outsider factors are considered. The model stand is supposed healthy, wood is ideally without any damages and the stand is fully-stocked.

\subsection{The Mensuration and Growth Tables (MGT)}

Data about merchantable volume in age classes of five years is available from the Mensuration and Growth Tables (MGT) of the main tree species of the Czech Republic [3], where the left part of the tables represents the mensuration tables plus indicating the basic stand characteristics of the present stands and the right part of the tables is the growth table itself. It indicates the predicted development of selected stand characteristics for the main stand (mean height, mean diameter, merchantable volume) and the thinning (merchantable volume).

Allowable cuts (merchantable volume) are set from MGT, and from the regulation No. 84/1996 Coll., About forest planning, for their comparison [19]. The volume of cuts is used for calculation of costs and revenues for the model stand.

\subsection{Costs Calculation}

Necessary costs are divided into two groups: silviculture, which includes protective costs and logging, which includes cutting, crosscutting, delimbing and skidding. Wood is sold on roadside. Other costs e. g. cost of road maintenance, amelioration, management were not considered because they could be very different according to the locality.

Silviculture and logging costs were calculated from moment of stand regeneration to harvest cut. Stand is regenerated by 4,000 four-years-old plants of SM and 9,000 threeyears-old plants of BK. Spruce is planted by hole planting and beech by slit planting to the full-area soil prepared. BK plants are full-area fenced up to $50 \%$ of its composition. With higher BK composition the fenced area decreases to $20 \%$ in case of pure BK stand. In the first three years the SM is scythed two times a year in lines and BK in full-area, SM is painted against pine weevil and against game browsing in autumn. Then the next three years the scything is done only once a year and protection against game browsing annually decreases by $20 \%$ in older trees. When the BK plantation is established the fence is removed and stand is tended. In the age of 10 to 15 years in the moment of canopy closure the negative selection crown thinning is executed and $30 \%$ of SM trees are removed. $30 \%$ of subdominant and codominant $\mathrm{BK}$ trees is removed.

In stands of ages 20 to 95 years thinning is executed. In pure SM stands and mixed stands with minimum composition preventive measures must be taken according to regulation No. 236/2000 Sb., which altered Decree of the Ministry of Agriculture of the Czech Republic No. 101/1996 Coll., setting forth details for securing forest protection and stating models of service badge and of forest guard certificate [20]. Basic condition of Ips typographus is observed by insect trapping (cut control spruce stems, the so called trap trees, or installation of pheromone-baited traps), which are installed in spring and summer seasons in minimum of one trap on each 5 hectares of forest stands older than 60 years with at least SM20.

Used prices of all activities are reported in appendix No. 1, there are prices of contractors including their profit margin.

$$
\begin{gathered}
C=n_{s m} A p_{s m}+n_{b k} A p_{b k}+n A p_{0}+n A p_{1}+ \\
+n A p_{2}+n A p_{3}+n A p_{4}+n p_{5}+A c_{p}+n_{l p} p_{l p}+ \\
+E_{1} A c_{p r(s m, b k)}+E_{2} A c_{p r o(s m, b k)}+E_{3} A c_{t(s m, b k)}
\end{gathered}
$$

$n_{x}-$ number of units (operations or meters of fence),

$n_{s m, b k}-$ number of plants,

$n_{l p}-$ number of traps,

$p_{s m, b k}$ - plant price included its planting,

$p_{l p}-$ price of traps included its control and remediation,

$A$ - area of silvicultural or logging operation in ha, $1 \mathrm{~m}^{3}$,

$E_{1,2,3}$ - volume of cut with bark deduction in

$p_{0}$ - price of full-area site preparation,

$p_{1}-$ price of scything in lines $50 \mathrm{~cm}$ for $1 \mathrm{ha}$,

$p_{2}$ - price of full-area scything for 1 ha,

$p_{3}-$ price for painting against spruce brows for 1 plant (including work and material), 
$p_{4}$ - price for painting 1 ha against weevil (including work and material),

$p_{5}$ - price one running meter for a fence building and disposal,

$c_{p(s m, b k)}-$ costs of clearing on 1 ha $(30 \%$ reduction),

$c_{p r(s m, b k)}$ - costs of thinning and skidding of $1 \mathrm{~m}^{3}$ of softwood and broadleaved species in forests up to 40 years,

$c_{\text {pro }(s m, b k)}-$ costs of thinning and skidding of $1 \mathrm{~m}^{3}$ of softwood and broadleaved species in forest older than 40 years,

$c_{t(s m, b k)}$ - costs of harvest cut and skidding of $1 \mathrm{~m}^{3}$ of and softwood and broadleaved species.

\subsection{Revenues Calculation}

Revenues from the model stand were calculated as a product of cubic capacity harvested assortments and its price on roadside, which is recorded by the Czech statistical office to the roadside place [4].

$R=M_{1} A p_{6}+M_{2} A p_{7}+M_{3} A p_{8}$

$p_{6-8}-$ wood price according assortments,

$M_{1}$ - volume of timber of assortments of III. $\mathrm{A} / \mathrm{B}$ quality class according to the Czech state norm (ČSN),

$\mathrm{M}_{2}$ - volume of timber of assortments of IV. quality class according to the ČSN,

$M_{3}$ - volume of timber of assortments of $\mathrm{V}$. quality class according to the ČSN (fuel wood),

$A$ - area of species in model stand.

\subsection{Profit from the Model Stand}

The total profit does not include any tax or forest administration costs. For the research the profit means difference between costs and revenues. In case that result is negative there is loss and not profit.

$$
P=R-C
$$

\section{Results}

Firstly values of cuts were set up for calculations of revenues and costs. Actual prices for year 2012 were used, which could differ from one contractor to another one and which includes their profit margin. For wood assortments an average price for wood for the third quadrant last year 2012 were used. It is publicly available from the Czech statistical office (ČSÚ) webpage [4]. This price is of wood on roadside.

\subsection{Allowable Intermediate Cut}

According to regulation No. 84/1996 Coll., on forest management planning, for pure spruce and beech stands of higher site index there is percentage value of allowable intermediate cut including natural mortality for each decennial period and for full stocking (see Tab. 1 and 2). In the tables below there are values from the Mensuration and Growth Tables (MGT), which were summed for 10 years period for better comparison because in the MGT there are fiveyear periods stated. The values from the MGT for spruce up to 70 years are higher and then mainly lower according to the regulation for site index +1 . In average the volumes are almost equal. Volumes are compared without that of age of 20 years because there is no data for allowable intermediate cut for spruce till the age of 30 years in the MGT. For beech both volumes are almost equal at sum. The volumes in the MGT are lower than regulation ones and they were used for the calculations. In this way overvaluation of incomes is potentially avoided.

\subsection{Harvested Timber and Its Assortments}

Volume of timber harvested from model stands were established according to real timber supply from the MGT as well as intermediate cut. All cuts were sorted by their diameter at breast height according to the Assortment tables [17 with groundwork by Dejmal 1986]. Bark deduction was made differently according to their diameter at breast height were used different coefficient. Example of calculation is in appendix No. 2. In case of spruce the used category was: standard for stacked and healthy wood with average technological quality standards. In case of beech followed category was used - standard for stacked and healthy wood with average technological quality standards including branch wood. Shares of assortments in the model stand are shared as followed (Tab. 3). 


\section{Ekonomika a management}

\begin{tabular}{|c|c|c|c|c|}
\hline Tab. 1 & $\begin{array}{l}\text { Comparison of } \\
\text { index }+1(36)\end{array}$ & vable intermedi & ut for pure spruce & tand with site \\
\hline \multirow[t]{2}{*}{ Age } & \multirow{2}{*}{$\begin{array}{l}\text { Timber to the top } \\
\text { of } 7 \mathrm{~cm} \text { o.b. } \\
\text { (in } \mathrm{m} / \mathrm{ha} \text { ) }\end{array}$} & \multicolumn{2}{|c|}{$\begin{array}{c}\text { An allowable intermediate cut according to the } \\
\text { regulation }\end{array}$} & \multirow{2}{*}{$\begin{array}{c}\text { An allowable intermediate } \\
\text { cut according to the MGT } \\
\text { (in } \mathrm{m}^{3} / \mathrm{ha} \text { ) }\end{array}$} \\
\hline & & $\begin{array}{l}\text { Timber to the top } \\
\text { of } 7 \mathrm{~cm} \text { o.b. (in \%) }\end{array}$ & $\begin{array}{l}\text { Timber to the top } \\
\text { of } 7 \mathrm{~cm} \text { o.b. (in } \mathrm{m}^{3} / \mathrm{ha} \text { ) }\end{array}$ & \\
\hline 30 & 294 & 24 & 70.6 & 77.0 \\
\hline 40 & 423 & 17 & 71.9 & 77.0 \\
\hline 50 & 534 & 12 & 64.1 & 71.0 \\
\hline 60 & 628 & 10 & 62.8 & 63.0 \\
\hline 70 & 716 & 8 & 57.3 & 58.0 \\
\hline 80 & 785 & 7 & 55.0 & 54.0 \\
\hline 90 & 847 & 6 & 50.8 & 52.0 \\
\hline 100 & 900 & 6 & 71.4 & 50.0 \\
\hline \multicolumn{3}{|l|}{ Total } & 503.9 & 502.0 \\
\hline
\end{tabular}

Source: Calculated form the MGT and regulation No. 84/1996 Coll., About forest planning.

\begin{tabular}{|c|c|c|c|c|}
\hline Tab. 2 & $\begin{array}{l}\text { Comparison of } \\
\text { index }+1(36)\end{array}$ & vable intermed & It for pure beech & and with site \\
\hline \multirow[t]{2}{*}{ Age } & \multirow{2}{*}{$\begin{array}{l}\text { Timber to the top } \\
\text { of } 7 \mathrm{~cm} \text { o.b. } \\
\text { (in } \mathrm{m}^{3} / \mathrm{ha} \text { ) }\end{array}$} & \multicolumn{2}{|c|}{$\begin{array}{c}\text { An allowable intermediate cut according to the } \\
\text { regulation }\end{array}$} & \multirow{2}{*}{$\begin{array}{l}\text { An allowable intermediate } \\
\text { cut according to the MGT } \\
\text { (in } \mathrm{m}^{3} / \mathrm{ha} \text { ) }\end{array}$} \\
\hline & & $\begin{array}{l}\text { Timber to the top } \\
\text { of } 7 \mathrm{~cm} \text { o.b. (in \%) }\end{array}$ & $\begin{array}{l}\text { Timber to the top } \\
\text { of } 7 \mathrm{~cm} \text { o.b. (in } \mathrm{m}^{3} / \mathrm{ha} \text { ) }\end{array}$ & \\
\hline 20 & 118 & - & - & - \\
\hline 30 & 220 & 21 & 46.2 & 70 \\
\hline 40 & 303 & 21 & 63.6 & 75 \\
\hline 50 & 381 & 18 & 68.6 & 68 \\
\hline 60 & 454 & 16 & 72.6 & 60 \\
\hline 70 & 527 & 13 & 68.5 & 56 \\
\hline 80 & 591 & 11 & 65.0 & 54 \\
\hline 90 & 655 & 10 & 65.5 & 56 \\
\hline 100 & 711 & 9 & 64.0 & 55 \\
\hline \multicolumn{3}{|l|}{ Total } & 514.0 & 494 \\
\hline
\end{tabular}

Source: Calculated form the MGT and regulation No. 84/1996 Coll., About forest planning.

Data was got from the MGT as values of total cuts from major harvest and allowable intermediate cuts. The Tab. 4 below presents example of the volumes for site index 36 and 16 for pure spruce stand and pure beech stand and equally mixed stand. Situation is similar in others site indexes. Total volume is almost the same for another species composition. There is a difference between volumes in various stand growth stages. Whereas the major harvest is in any situation higher in case of pure spruce stand, opposite situation is in all cuts before major harvest in case of pure beech stand or its mixtures. 
Tab. 3: Assortment shares of different site indexes in case of spruce and beech

\begin{tabular}{l|c|c|c|c|c|c|c|c|c|c|c}
\multirow{2}{*}{ Assortment } & \multicolumn{10}{c}{ Assortment shares of different site indexes } \\
\cline { 2 - 13 } & \multicolumn{10}{|c}{ spruce } \\
\cline { 2 - 13 } & $\mathbf{3 6}$ & $\mathbf{3 4}$ & $\mathbf{3 2}$ & $\mathbf{3 0}$ & $\mathbf{2 8}$ & $\mathbf{2 6}$ & $\mathbf{2 4}$ & $\mathbf{2 2}$ & $\mathbf{2 0}$ & $\mathbf{1 8}$ & 16 \\
\hline III. A/B grade & 0.8510 & 0.8317 & 0.8054 & 0.8057 & 0.7773 & 0.7139 & 0.7219 & 0.6168 & 0.6156 & 0.6109 & 0.6102 \\
\hline V. grade & 0.1219 & 0.1414 & 0.1684 & 0.1679 & 0.2034 & 0.2669 & 0.2588 & 0.3639 & 0.3650 & 0.3699 & 0.3706 \\
\hline Fuel wood & 0.0272 & 0.0269 & 0.0262 & 0.0263 & 0.0193 & 0.0192 & 0.0193 & 0.0192 & 0.0194 & 0.0192 & 0.0192 \\
\hline & \multicolumn{10}{|c|}{ beech } \\
\hline III. A/B grade & 0.6645 & 0.6384 & 0.6360 & 0.6414 & 0.6414 & 0.6549 & 0.6371 & 0.6699 & 0.6538 & 0.6425 & 0.6213 \\
\hline V. grade & 0.2828 & 0.3110 & 0.3140 & 0.3139 & 0.3139 & 0.3001 & 0.3179 & 0.2847 & 0.3020 & 0.3192 & 0.3408 \\
\hline Fuel wood & 0.0526 & 0.0506 & 0.0500 & 0.0447 & 0.0447 & 0.0450 & 0.0450 & 0.0454 & 0.0442 & 0.0383 & 0.0379 \\
\hline
\end{tabular}

Source: Calculated form the Assortment tables and the MGT used methodology above.

Tab. 4: Volume of cut in model stands of site index 36 and 16

\begin{tabular}{l|c|c|c|c|c|c}
\multirow{2}{*}{ Items with bark deduction } & \multicolumn{2}{|c|}{$\begin{array}{c}\text { Volume of cut in site } \\
\text { index 36 in } \mathbf{m}^{3}\end{array}$} & \multicolumn{3}{|c}{$\begin{array}{c}\text { Volume of cut in site } \\
\text { index 16 in } \text { m }^{3}\end{array}$} \\
\cline { 2 - 7 } & SM100 & SM50 & BK100 & SM100 & SM50 & BK100 \\
\hline Volume of cut up to age 40 years $\left(\mathrm{E}_{1}\right)$ & 146.94 & 149.08 & 151.22 & 0.00 & 0.00 & 0.00 \\
\hline Volume of cut over 40 years $\left(\mathrm{E}_{2}\right)$ & 350.08 & 404.27 & 458.46 & 64.80 & 94.71 & 124.63 \\
\hline Major harvest $\left(\mathrm{E}_{3}\right)$ & 820.62 & 745.54 & 670.47 & 240.97 & 183.00 & 125.03 \\
\hline Total & $1,317.64$ & $1,298.89$ & $1,280.15$ & 305.77 & 277.71 & 249.66 \\
\hline Volume of III. A/B grade of quality $\left(\mathrm{M}_{1}\right)$ & $1,121.28$ & 985.99 & 850.70 & 186.57 & 170.83 & 155.10 \\
\hline Volume of V. grade of quality $\left(\mathrm{M}_{2}\right)$ & 160.55 & 261.31 & 362.07 & 113.32 & 99.20 & 85.09 \\
\hline Volume of fuel wood, Vl. grade of quality $\left(\mathrm{M}_{3}\right)$ & 35.81 & 51.595 & 67.38 & 5.88 & 7.67 & 9.47 \\
\hline
\end{tabular}

Source: Results from calculations according to the methodology.

Share of total volume of spruce and beech harvested timber is shown in the Fig. 1. In the model stand the amount of beech harvested timber does not decrease fewer than $74 \%$ of spruce harvested timber. In average beech harvested timber comprises about $81 \%$ of spruce harvested timber.

\subsection{Costs and Revenues Calculations}

Using the previous results of harvested timber and its assortments the costs and revenues for model stand in all site indexes and mixtures of spruce and beech were calculated (tab. 5 and 6). 


\section{Ekonomika a management}

\section{Fig. 1: Share of total volume of spruce and beech cuts}

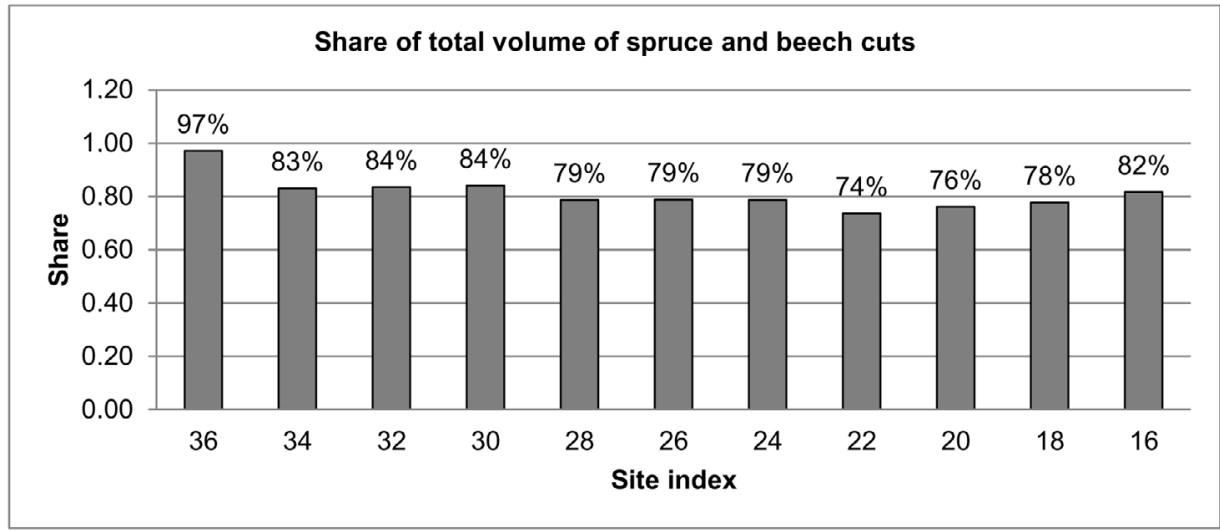

Source: Results from calculations according to the methodology.

\begin{tabular}{|c|c|c|c|}
\hline Tab. 5: $\begin{array}{l}\mathbf{E} \\
\text { al }\end{array}$ & $\begin{array}{l}\text { mple of costs calculation for } \\
\text { SM100, BKO }\end{array}$ & del stand in site index & \\
\hline$C=$ & Costs of & Calculations & \\
\hline$n_{s m} A p_{s m}$ & planting of spruce & $4,000^{*} 1^{*}(10+5)$ & 60,000 \\
\hline$n_{b k} A p_{b k}$ & planting of beech & $9,000 * 0 *(8+4.8)$ & 0 \\
\hline$n p_{0}$ & full-area site preparation & $1 * 2,000$ & 2,000 \\
\hline$n A p_{1}$ & scything in lines & $1^{*} 7^{\star} 5,000$ & 35,000 \\
\hline$n A p_{2}$ & full-area scything & $0 * 7 * 8,000$ & 0 \\
\hline$n A p_{3}$ & painting against spruce brows & $4,000 *(1+1+0.8+0.6+0.4)^{*} 1^{*} 1.2$ & 18,240 \\
\hline$n A p_{4}$ & painting against weevil & $1 * 2,620 * 3$ & 7,860 \\
\hline$n p_{5}$ & building and disposal of a fence & $0 * 90$ & 0 \\
\hline$A c_{p}$ & clearing $-30 \%$ reduction & $1 * 9,600$ & 9,600 \\
\hline$n_{1 p} p_{l p}$ & traps including control and remediation & $16^{*} 1 * 600$ & 9,600 \\
\hline$E_{1} A c_{p r(s m)}$ & thinning and skidding (age $<40$ years) & $146.94^{*} 1^{*} 1,020$ & 149,879 \\
\hline$E_{1} A c_{p r(b k)}$ & & $151.22 * 0 * 780$ & 0 \\
\hline$E_{2} A c_{\text {pro }(s m)}$ & thinning and skidding (age > 40 years) & $350.08^{*} 1^{*} 660$ & 231,053 \\
\hline$E_{2} A c_{\text {pro }(b k)}$ & & $458.46^{\star} 0^{*} 660$ & 0 \\
\hline$E_{3} A c_{t(s m)}$ & harvest cut and skidding & $820.62^{*} 1^{*} 660$ & 541,609 \\
\hline$E_{3} A c_{t(b k)}$ & & $670.47^{\star} 0.684$ & 0 \\
\hline Total costs $(C)$ & & & $841 \mathrm{CZK}$ \\
\hline
\end{tabular}

Source: Calculation according to the equation (1) 


\begin{tabular}{|c|c|c|c|}
\hline \multirow{2}{*}{$\begin{array}{l}\text { Tab. 6: } \\
\mathbf{R}=\end{array}$} & \multicolumn{3}{|c|}{$\begin{array}{l}\text { Example of costs calculation for model stand in site index }+1(36) \\
\text { and SM100, BKO }\end{array}$} \\
\hline & Revenues of & Calculation & \\
\hline$M_{1} A p_{6}$ & timber of assortments of III. A/B quality class & $1,121 \cdot 277^{\star} 11^{\star} 2,098$ & $2,352,439$ \\
\hline$M_{2} A p_{7}$ & timber of assortments of IV. quality class & $160.557^{\star} 1^{*} 860$ & 138,079 \\
\hline$M_{3} A p_{8}$ & timber of assortments of V. quality class & $35.807^{\star} 1^{\star} 784$ & 28,073 \\
\hline \multicolumn{2}{|c|}{ Total revenues (R) } & \multicolumn{2}{|c|}{ 2,518,591 CZK } \\
\hline
\end{tabular}

Source: Calculation according to the equation (2)

Profit from model stand in site index +1 (36) and SM100, BK0 is:

$P=2,518,591-1,064,841=1,453,750 \mathrm{CZK}$

In the table 7 below you can see some other results for next two site indexes and different species compositions. Average costs for established plantation are 133,000 CZK per hectare in pure spruce stand and 237,000 CZK per hectare in pure beech stand.

\section{Tab. 7: Profit from model stands in different site index and species compositions}

\begin{tabular}{l|c|c|c|c|c|c|c|c|c}
\multirow{2}{*}{ Item } & \multicolumn{2}{|c|}{$\begin{array}{c}\text { Cash flows for site index 36 } \\
\text { (CZK) }\end{array}$} & \multicolumn{2}{|c|}{$\begin{array}{r}\text { Cash flows for site index 26 } \\
\text { (CZK) }\end{array}$} & \multicolumn{2}{|c}{$\begin{array}{c}\text { Cash flows for site index 16 } \\
\text { (CZK) }\end{array}$} \\
\cline { 2 - 11 } & SM100 & SM50 & BK100 & SM100 & SM50 & BK100 & SM100 & SM50 & BK100 \\
\hline $\begin{array}{l}\text { Costs up to ten-year } \\
\text { old forest with scything }\end{array}$ & 132,700 & 184,750 & 237,232 & 132,700 & 184,750 & 237,232 & 132,700 & 184,750 & 237,232 \\
\hline Harvesting costs & 932,141 & 905,640 & 879,139 & 487,403 & 432,300 & 377,198 & 211,408 & 189,591 & 167,773 \\
\hline Total costs & $1,064,841$ & $1,090,390$ & $1,116,371$ & 620,103 & 617,050 & 614,430 & 344,108 & 374,341 & 405,005 \\
\hline Total revenues & $2,518,591$ & $2,104,007$ & $1,689,422$ & $1,234,116$ & 984,492 & 734,867 & 493,492 & 409,238 & 324,984 \\
\hline Profit (Loss) & $1,453,750$ & $1,013,617$ & 573,051 & 614,013 & 367,442 & 120,437 & 149,384 & 34,897 & $-80,021$ \\
\hline
\end{tabular}

Source: Results from calculations according to the methodology.

Established plantation costs grew $6 \%$ in average with growth $10 \%$ of beech in species composition. The main growth of the costs is between pure spruce stand and composition of SM90 and BK10, as seen in Fig. 2.

With calculation of weight average price of wood for spruce and beech stand using both the data from Tab. 3 and from profits from stands it is possible to confirm that the average is decreasing with site index of tree especially in spruce stands, whereas this decrease is not so noticeable in case of beech stand. The average price of spruce wood ranges in the highest site index (36) from $1,991 \mathrm{CZK} / \mathrm{m}^{3}$ to
$1,614 \mathrm{CZK} / \mathrm{m}^{3}$ for the lowest site index (16) and in case of beech wood from $1,319 \mathrm{CZK} / \mathrm{m}^{3}$ to $1,302 \mathrm{CZK} / \mathrm{m}^{3}$. Relative change is in Fig. 3.

Sorting process influences profit from spruce stands more than beech stands because of significant differences in assortment prices.

The average price of spruce wood reached $77 \%$ of III. A/B quality classification price and the average price of beech wood reached $90 \%$ of III. A/B quality classification price in the lowest site index. It responds to price differences between grades, where spruce wood price of fuel wood compared to III. A/B grade comprises $37 \%$ and $75 \%$ in case of beech. 


\section{Ekonomika a management}

\section{Fig. 2: Established plantation cost for different species composition}

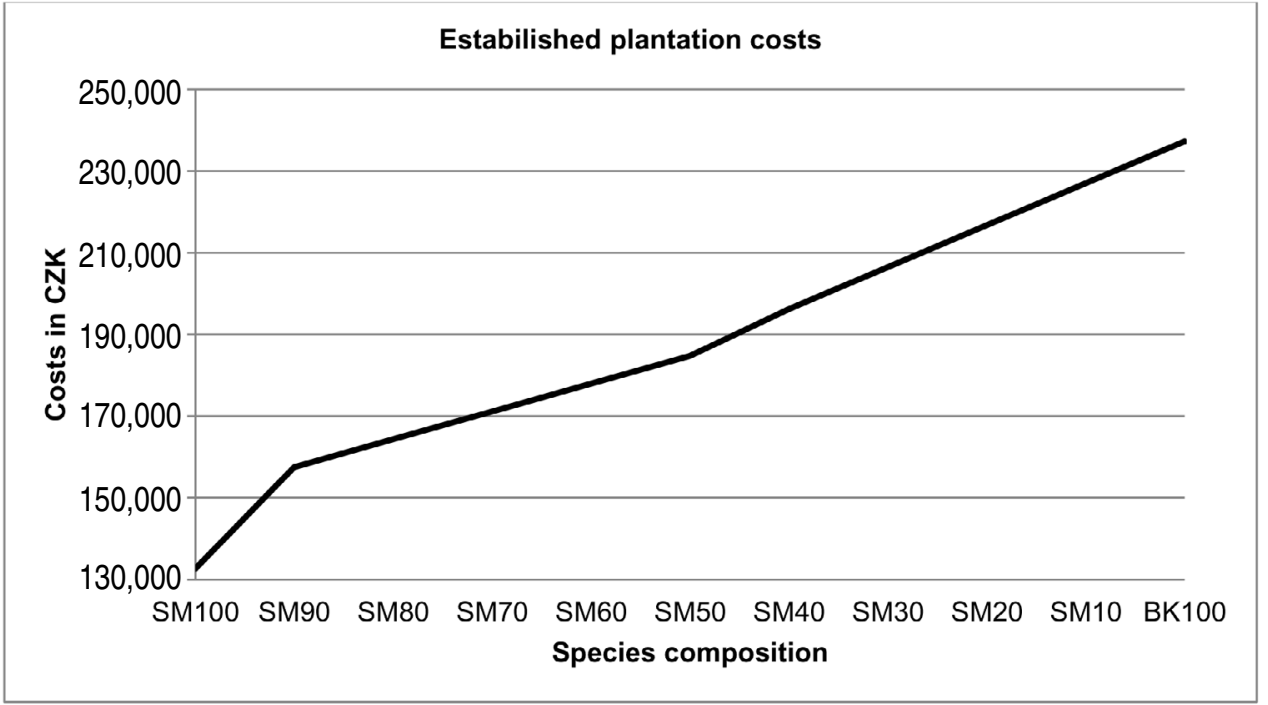

Source: Results from calculations according to the methodology.

\section{Fig. 3: Relative change of average wood price according to site index}

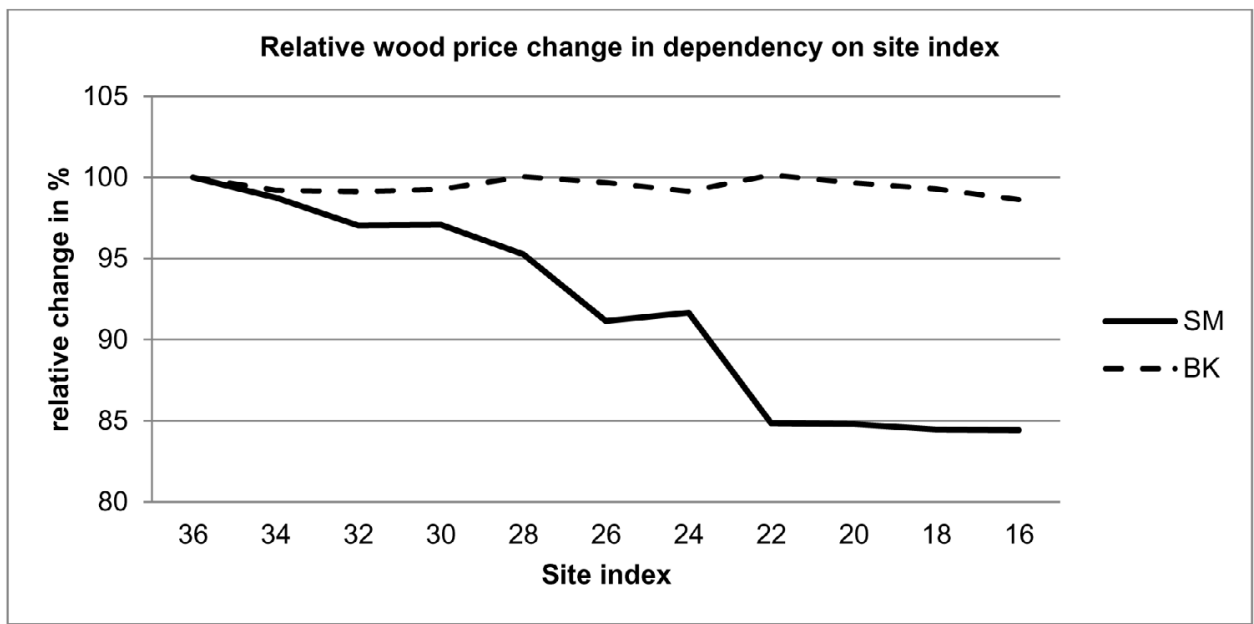

Source: Results from calculations according to the methodology 


\section{Business Administration and Management}

\subsection{Profit Dependency on Species Composition}

With the previously calculated prices results show that in stand with the highest site index the differences between profits in pure spruce stand and pure beech stand will be about 900,000 CZK, whereas in stands with the lower site index it will be $230,000 \mathrm{CZK}$.
The profit is decreasing linearly with dependency on species composition from SM100 to BK100. In lower site indexes this decrease is not so steep. In stands with composition BK80 with index 20 and lower there is loss. The Fig. 4 shows absolute values for all 121 model situations.

\section{Fig. 4: Dependency of profit from forest on species composition}

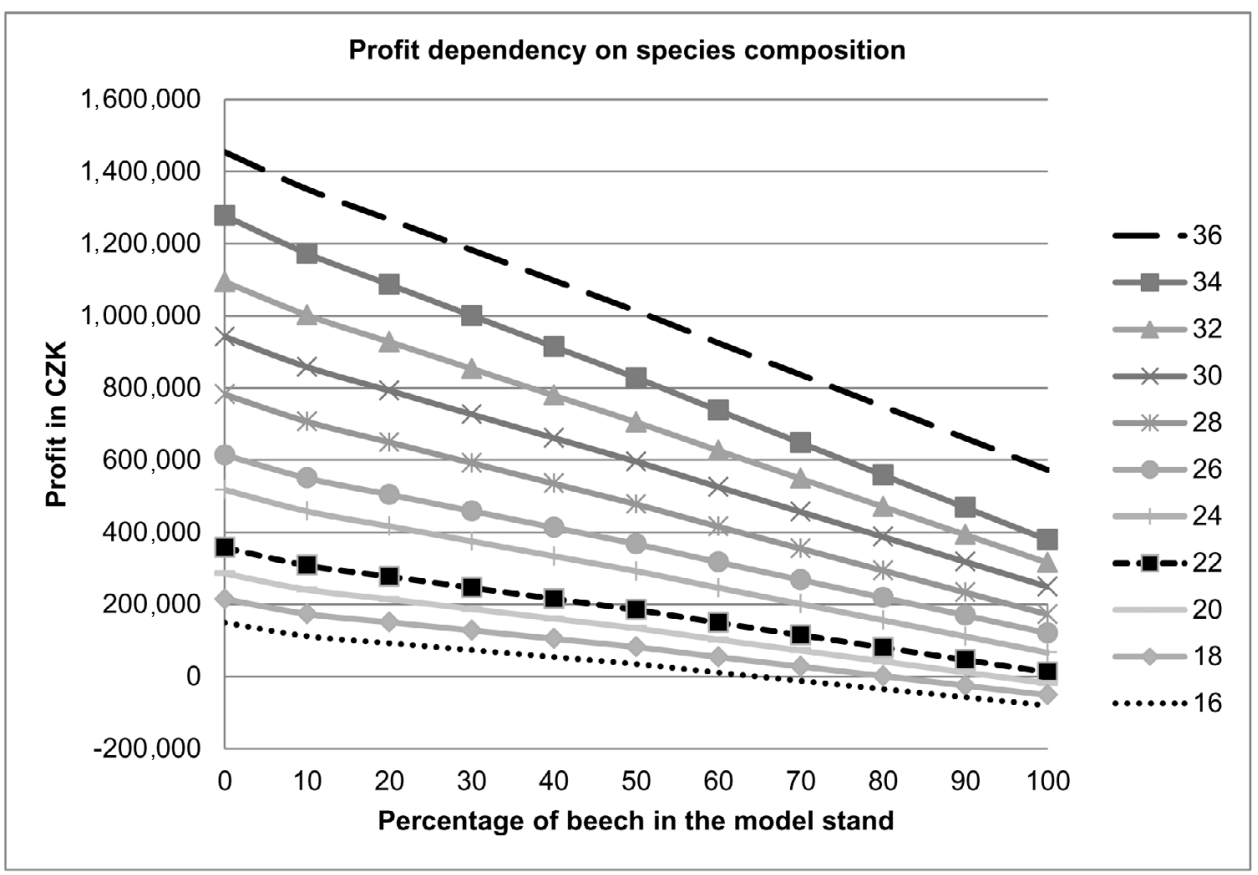

Source: Results from calculations according to the methodology.

Absolute relation between profit and species composition for various site indexes:

$y=p x+n$.

E.g. for site index $36: y=-8713 x+1,445,667$. For others site indexes coefficients are in Tab. 8 . 


\section{Tab. 8: Coefficients for different site indexes}

\begin{tabular}{c|c|c} 
Site index & $\mathbf{p}$ & $\mathbf{n}$ \\
\hline 36 & $-8,713.0$ & $1,445,667$ \\
\hline 34 & $-8,885.9$ & $1,268,901$ \\
\hline 32 & $-76,917.0$ & $1,085,997$ \\
\hline 30 & $-68,338.0$ & 933,855 \\
\hline 28 & $-60,036.0$ & 774,034 \\
\hline 26 & $-48,418.0$ & 605,929 \\
\hline 24 & $-44,193.0$ & 509,601 \\
\hline 22 & $-33,573.0$ & 348,967 \\
\hline 20 & $-29,479.0$ & 277,641 \\
\hline 18 & $-25,661.0$ & 206,535 \\
\hline 16 & $-22,001.0$ & 141,301 \\
\hline
\end{tabular}

Source: Results from calculations according to the methodology.

$n$ - profit from the model stand,

$p$ - differences between profit from pure spruce stand and pure beech stand divided by beech composition.

In case of mixture SM40 and BK60 at site index 36 the profit is approximately:

$$
y=60 x(-8,713)+1,445,667=\underline{922,877 \mathrm{CZK}}
$$

Tab. 9: $\begin{aligned} & \text { Coefficients for different site } \\
& \text { indexes }\end{aligned}$
\begin{tabular}{c|c|c|c} 
Site index & $\mathbf{p}$ & $\mathbf{n}$ & $\mathbf{R}^{\mathbf{2}}$ \\
\hline 36 & -0.0083 & 2.3427 & 0.9989 \\
\hline 34 & -0.0088 & 2.0330 & 0.9987 \\
\hline 32 & -0.0085 & 2.2327 & 0.9987 \\
\hline 30 & -0.0087 & 2.1992 & 0.9986 \\
\hline 28 & -0.0085 & 2.1124 & 0.9982 \\
\hline 26 & -0.0077 & 1.9676 & 0.9978 \\
\hline 24 & -0.0080 & 1.9175 & 0.9975 \\
\hline 22 & -0.0068 & 1.7036 & 0.9966 \\
\hline 20 & -0.0066 & 1.6182 & 0.9958 \\
\hline 18 & -0.0063 & 1.5109 & 0.9946 \\
\hline 16 & -0.0006 & 1.3892 & 0.9922 \\
\hline
\end{tabular}

Note: $R^{2}$ - coefficient of determination

Source: Results from calculations according to the methodology.
It is possible to express the graph (Fig. 4) relatively as a relation between profit and species composition for various site indexes:

$$
\begin{aligned}
& y=p x+n \\
& \text { E. g. for site index } 36: \\
& y=-0.0083 x+2.34
\end{aligned}
$$

\section{Conclusion}

Nowadays matters about forest stability are very important related to the climate changing, which could be met by owner or manager. Many scientists show an alarming condition of some of our forests and possible threats caused by biotic and abiotic agents.

The owner or manager can change species composition and influence the future profit from cut wood. From this point of view this profit is interesting gain from economic forest function because the others functions (as ecological and social) are not enough profitable yet in the Czech Republic.

The aim of this research was to prove that natural species composition is not as profitable as spruce monoculture in example of 4 th $\mathrm{fvz}$ (forest vegetation zone in nutrient stations). The profit from pure spruce stand is higher, so that beech stands are not lucrative for owners. Any state subsidiaries or other motivation tools for changing species composition were not considered.

On the model stand possible costs and revenues for all possible site indexes and various species compositions from pure spruce forest through mixtures of beech to pure beech forests were calculated. The cash flows were compared. The model stand includes 100 groups differ in age of one year. The same rotation period of 100 years and regeneration period of one year were considered for spruce and beech stands.

It was set up a number of silviculture and logging activities and the costs were calculated. Total volume of cuts was used from MGT (Mensuration and Growth Tables) for all site indexes with bark deduction. Revenues were calculated for wood assortments. There are used prices of forestry contractors including their profit margin and average price for wood assortments for the third quarter last year 2012 publicly available from the Czech statistical office related to the roadside.

The research was based on three hypotheses. Firstly the profit from the pure spruce stand is 
higher than the profit from pure beech stand. The revenues from spruce stand were

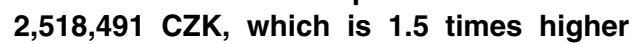
than beech ones, which were $1,689,422$ CZK in site index +1 (36). The costs for establishing plantation did not differ in absolute values so much. The difference between the revenues is caused mostly by different price for species assortments according to their quality. The volume of harvested SM and BK wood does not differ so significantly mainly in higher site indexes in pure stands or their mixtures too. In case of SM100 the volume of total cut was $1,317.64 \mathrm{~m}^{3}, \mathrm{SM} 50$, BK50 it was $1,298.89 \mathrm{~m}^{3}$ and BK100 it was $1,280.15 \mathrm{~m}^{3}$ (for site index 36 ). The volume of cuts is almost the same, there is a difference between the volume of wood harvested in forest group with age up to 40 years, older than 40 years and major harvest, where the major harvest is in any situation higher in case of pure spruce stand. Opposite situation is in all cuts before major harvest in case of pure beech stand or its mixtures.

Profitability of potential investment, which presents costs to the pure spruce stands with the highest site index +1 (36) is $234 \%$, whereas profitability of beech stand in the same site index is only $151 \%$.

The second hypothesis was confirmed only partly. It is true that lower SM composition causes lower profit. However, this is not caused by rising costs for established plantation, which are twice times higher in case of beech. Price differences of wood assortments have a bigger impact on the profit. Wood price is affected by various factors, which could be target for future research. The calculated average price for site index +1 (36) in case of SM is $1,990 \mathrm{CZK} / \mathrm{m}^{3}$ and for BK $1,319 \mathrm{CZK} / \mathrm{m}^{3}$. In comparison to Bartoš et al. [1], results from this research do not differ so significantly in case of BK. They got beech wood price $1,238 \mathrm{CZK} / \mathrm{m}^{3}$ and spruce price $1,273 \mathrm{CZK} / \mathrm{m}^{3}$ which differs more, whereas the differences between used prices were not so big. It could be influenced by various damages which could lower price and which were not taken in consideration in the model situation. Level of risk of lower profit could be next topic for following research.

Average costs for established plantation including the first $30 \%$ clearing were $132,700 \mathrm{CZK}$ in case of pure spruce stand and 237,232 CZK in case of pure beech stand. It could be decreased by lower amount of silviculture operations, but main cost comprises of planting. All the cash flows are related to the area of 100 ha, but all activities are done within one year. So, the results could be understood differently. The costs, revenues and profit are cash flows of 1 ha stand during 100 years.

The third hypothesis confirmed that amount of profit is influenced by species composition with certain amount of silviculture operations. Profit is a linear function of changing species composition. Intensity of silviculture operations could lower costs, but on the other hand it could lower volume of felling too. But this was not object of this research.

\section{References}

[1] BARTOŠ, J., ŠACH, F., KACÁLEK, D., ČERNOHOUS, V. Ekonomické aspekty druhového složení první generace lesa na bývalé zemědělské půdě. Zprávy lesnického výzkumu. 2007, Vol. 52, Iss. 1, pp. 11-17. ISSN 0322-9688.

[2] ČERMÁK, P., JANKOVSKÝ, L., CUDLÍN, P. Risk evaluation of the climatic change impact on secondary Norway spruce stands as exemplified by the Krrtiny Training Forest Enterprise. Journal of Forest Science. 2004, Vol. 50, Iss. 6, pp. 256-262. ISSN 1212-4834.

[3] ČERNÝ, M., PAŘEZ, J., MALÍK, Z. Růstové modely hlavních dřevin České republiky (Mensuration and Growth Tables of the Main Tree Species of the Czech Republic). (smrk, borovice, buk, dub), Př́loha č. 3 vyhlášky Ministerstva zemědělství č. 84/1996 Sb. o lesním hospodářském plánování (částka 28/1996 Sbírky zákonů). Jílové u Prahy: IFER -Ústav pro výzkum lesních ekosystémů, s. r. o., 1996, p. 245.

[4] ČSÚ. Průměrné ceny surového dřiví pro tuzemsko za ČR v roce $2011\left(\mathrm{Kč} / \mathrm{m}^{3}\right)$ [online]. Praha: Český statistický úřad, c2013 [vid. 2013-04-04]. Available from: http://www.silvarium.cz/images/ stories/VLASTNCI__Prmrn_ceny_surov ho_dv_pro_tuzemsko_za_R_v_roce_2011.pdf.

[5] HALAJ, J. Prieskum výškovej vzrastavosti drevín na Slovensku a návrh stupnic výškových bonít. Lesnický časopis. 1959, Vol. 5, Iss. 3-4, pp. 21-40. ISSN 0323-1046.

[6] INDIRA, P. Podíl jedle bělokoré ve výhledových cílech obnovy lesa u LČR. Lesnická práce [online]. 2002, Vol. 81, Iss. 1 [vid. 2013-01-04], pp. 20-21. Available from: http://www.silvarium.cz/lesnickaprace-c-1-02/podil-jedle-belokore-ve-vyhledovychcilech-obnovy-lesa-u-Icr. ISSN 0322-9254. 
[7] JANČAŘíK, V. Nekrotická onemocnění a další poškození kůry buku (Necrotic diseases and other bark damage of beech). Zpravodaj ochrany lesa. 2004, Iss. 10, pp. 6-9. ISBN 80-86461-47-5.

[8] JANKOVSKÝ, L., CUDLÍN, P. Dopad klimatických změn na zdravotní stav smrkových porostů středohor. Lesnická práce. 2002, Vol. 81, Iss. 3, pp. 106-109. ISSN 0322-9254.

[9] MANSFELD, V. Vyšetření průběhu střední výšky smrku ztepilého Picea abies (L.) Karst. v lesních ekosystémech ČR na základě dat Národní inventarizace lesů. Dizertační práce. ČZU v Praze, 2002.

[10] MANSFELD, V. Norway spruce in forest ecosystems of the Czech Republic in relation to different forest site conditions. Journal of Forest Science [online]. 2011, Vol. 57, Iss. 11 [vid. 201208-02], pp. 514-522. Available from: http://www. agriculturejournals.cz/publicFiles/52122.pdf. ISSN 1212-4834.

[11] Ministerstvo zemědělství České republiky. Souhrnná zpráva 2009 (Report about condition of Czech forests) [online]. Praha: MZČR, 2009 [vid. 2012-08-02]. Available from: http://eagri.cz/public/ web/file/94596/Souhrn._zpr._2009_final.pdf.

[12] Ministerstvo zemědělství České republiky. Zpráva o stavu lese a lesního hospodářství České republiky $v$ roce 2010 (Report about forest condition and forest management in the Czech republic in year 2010) [online]. Praha: MZČR, 2010 [vid. 2012-08-03]. Available from: http://eagri.cz/public/ web/file/138583/Zprava_o_stavu_lesa_2010.pdf.

[13] NFI, ÚHÚL. National Forest Inventory in the Czech Republic 2001-2004: Introduction, Methods, Results [online]. Brandýs nad Labem: ÚHÚL, 2004 [vid. 2012-06-26]. pp. 224. Available from: ftp://ftp.uhul.cz/Public/NIL/PUBLIKACE_ NIL/NIL\%20CR\%202001-2004\%20cela\%20 kniha_NFI\%20CZ\%202001-2004\%20complete \%20book/NIL\%20CR\%202001-2004_NFI\% 20CZ\%202001-2004.pdf. ISBN 978-80-7084-587-5.

[14] PLÍVA, K. Typologický klasifikační systém ÚHUL Brandýs nad Labem [online]. Brandýs nad Labem: ÚHÚL, 1987 [vid. 2012-08-01]. Available from: ftp://ttp.uhul.cz/public/typologie/Typologicky_ klasifikacni_system_UHUL_Pliva_1987.pdf
[15] PRETZSCH, H. The elasticity of growth in pure and mixed stands of Norway spruce (Picea abises [L.] Karst.) and common beech (Fagus sylvatica L.). Journal of Forest Science. 2003, Vol. 49, Iss. 11, pp. 491-501. ISSN 1212-4834.

[16] SOUČEK, J., TESAR̆, V. Metodika přestavby smrkových monokultur na stanovištích přirozených smíšených porostů (Guidelines on Norway Spruce stand Transformation on Sites Naturally Dominated by Mixed Forset Stands). Recenzovaná metodika. Opočno. Lesnický průvodce [online]. 4/2008 [vid. 2012-06-26]. Available from: http://www.vulhm.cz/sites/File/vydavatelska_cinno st/lesnicky_pruvodce/lp_2008_04.pdf.

[17] Tabulky pro druhování dř́ví a sortimentaci těžebního fondu. Sestavil: Simanov, V. MZLU v Brně, 2007.

[18] TOMÁŠKOVÁ, I. Evaluation of changes in the tree species composition of Czech forests. Journal of Forest Science [online]. 2004, Vol. 50, Iss. 1 [vid. 2012-06-26], pp. 31-37. Available from: http://www.cazv.cz/attachments/2_1_0_Full\%20te xt\%205.pdf. ISSN 1212-4834.

[19] Vyhláška č. 84/1996 Sb., o lesním hospodářském plánování (on forest management planning). [20] Vyhláška č. 236/2000 Sb., kterou se mění vyhláška Ministerstva zemědělství č. 101/1996 Sb., kterou se stanoví podrobnosti o opatřeních k ochraně lesa a vzor služebního odznaku a vzor průkazu lesní stráže (setting forth details for securing forest protection and stating models of service badge and of forest guard certificate).

Ing. Pavlína Köhler, Ph.D.

Silesian University in Opava School of Business Administration in Karvina

Department of Finance and Accounting pavlina.kohler@tyra.cz

Ing. Vlastimil Vala, CSc. Mendel University in Brno Faculty of Forestry and Wood Technology Department of Forest and Wood Products

Economics and Policy vlastimil.vala@mendelu.cz 


\section{Appendix 1: Price list of operations and wood}

\begin{tabular}{|c|c|}
\hline Operations ${ }^{*}$ & Price in CZK \\
\hline$p_{0}-$ full-area site preparation (1 ha) & 2,000 \\
\hline$p_{s m}$ - plant price SM $(12-25 \mathrm{~cm})$ and Whole planting price for one plant & $10+5$ \\
\hline$p_{b k}-$ plan price BK $(36-50 \mathrm{~cm})$ and Slit planting price for one plant & $8+4.8$ \\
\hline$p_{1}-$ price of scything in lines $50 \mathrm{~cm}$ for 1 ha & 5,000 \\
\hline$p_{2}-$ price of full-area scything for 1 ha & 8,000 \\
\hline$p_{3}-$ price for painting against spruce brows for 1 plant & 1.2 \\
\hline $\begin{array}{l}p_{4} \text { - price for painting } 1 \text { ha against weevil - SM - work (1,000 CZK); material } \\
\text { (Primor, } 1 \mathrm{~kg} \text { on one ha; } 1,620 \mathrm{CZK} \text { ) }\end{array}$ & 2,620 \\
\hline$p_{5}-$ price of running meter of fence and disposal & $80+10$ \\
\hline$c_{p}-$ costs of clearing on 1 ha ( $30 \%$ reduction) & 9,600 \\
\hline$c_{\text {pr.sm }}-$ costs of thinning and skidding of $1 \mathrm{~m}^{3}$ of softwood & $660+360$ \\
\hline$c_{p r b k}-$ costs of thinning and skidding of $1 \mathrm{~m}^{3}$ of broadleaves & $420+360$ \\
\hline$c_{\text {pro.sm }}-$ costs of thinning and skidding of $1 \mathrm{~m}^{3}$ of softwood in forest older than 40 years & $300+360$ \\
\hline$c_{\text {probk }}-$ costs of thinning and skidding of $1 \mathrm{~m}^{3}$ of broadleaves $\mathrm{s}$ in forest older than 40 years & $300+360$ \\
\hline $\begin{array}{l}p_{1 p}-\text { price of one trap includes its control and sanation (one piece is required two times } \\
\text { a year on each } 5 \text { hectares in forests younger then } 40 \text { years) }\end{array}$ & 600 \\
\hline$c_{t, s m}-$ costs of harvest cut and skidding of $1 \mathrm{~m}^{3}$ of and softwood & $300+360$ \\
\hline$c_{t, b k}-$ costs of harvest cut and skidding of $1 \mathrm{~m}^{3}$ of and softwood and broadleaved species & $324+360$ \\
\hline \multicolumn{2}{|l|}{ Wood grade of quality** } \\
\hline$p_{6}-S M-I I I . A / B$ quality classification according to the Czech state norm (ČSN) & 2,098 \\
\hline$p_{7}-S M$ V. quality classification according to the ČSN & 860 \\
\hline$p_{8}-S M$ VI. quality classification according to the ČSN - fuel wood & 784 \\
\hline$p_{6}-\mathrm{BK}-$ III. A/B quality classification according to the ČSN & 1,453 \\
\hline$p_{7}-$ BK V. quality classification according to the ČSN & 1,050 \\
\hline$p_{8}-$ BK VI. quality classification according to the ČSN - fuel wood & 1,086 \\
\hline
\end{tabular}




\section{Appendix 2: Example of the SM sorting, site index +1 (36)}

\begin{tabular}{|c|c|c|c|c|c|c|c|c|c|c|c|c|}
\hline \multirow{3}{*}{$\begin{array}{c}\text { Age } \\
\\
15 \\
\end{array}$} & \multirow{3}{*}{$\begin{array}{l}\text { Stock } \\
\left(\mathrm{m}^{3}\right)^{*}\end{array}$} & \multirow{3}{*}{$\begin{array}{l}\text { Cut } \\
\left(m^{3}\right)^{*}\end{array}$} & \multirow{3}{*}{$\begin{array}{c}d_{1,3} \text { with } \\
\text { bark } \\
(\mathrm{cm})^{*}\end{array}$} & \multirow{3}{*}{$\begin{array}{c}\text { Bark } \\
\text { dedu- } \\
\text { ction }^{\star *}\end{array}$} & \multirow{3}{*}{$\begin{array}{c}\text { Cut with } \\
\text { bark } \\
\text { dedu- } \\
\text { ction }\left(m^{3}\right)\end{array}$} & \multicolumn{7}{|c|}{ Volume of harvested assortments with bark deduction $\left(\mathrm{m}^{3}\right)$} \\
\hline & & & & & & \multicolumn{4}{|c|}{ III. A } & \multirow{2}{*}{$\begin{array}{l}\text { III.B } \\
1 . b \\
\end{array}$} & \multirow{2}{*}{$\begin{array}{l}\text { pulp } \\
\text { wood }\end{array}$} & \multirow{2}{*}{$\begin{array}{l}\text { fuel } \\
\text { wood }\end{array}$} \\
\hline & & & & & & 1.b & 2.a & 2.b & 3. & & & \\
\hline 20 & 152.00 & & 11.90 & & & & & & & 0.00 & 0.00 & 0.00 \\
\hline 25 & 223.00 & 34.00 & 14.30 & 0.8777 & 29.84 & & & & & 6.57 & 22.98 & 0.30 \\
\hline 30 & 294.00 & 43.00 & 16.50 & 0.8826 & 37.95 & & & & & 17.08 & 20.12 & 0.76 \\
\hline 35 & 358.00 & 45.00 & 18.60 & 0.8872 & 39.92 & & & & & 17.97 & 21.16 & 0.80 \\
\hline 40 & 423.00 & 44.00 & 20.70 & 0.8914 & 39.22 & 0.78 & 16.87 & & & 8.63 & 12.16 & 0.78 \\
\hline 45 & 477.00 & 42.00 & 22.70 & 0.8951 & 37.59 & 0.75 & 16.16 & & & 8.27 & 11.65 & 0.75 \\
\hline 50 & 534.00 & 39.00 & 24.60 & 0.8979 & 35.02 & 0.35 & 23.46 & & & 4.20 & 6.30 & 0.70 \\
\hline 55 & 582.00 & 37.00 & 26.40 & 0.9005 & 33.32 & 0.33 & 22.32 & & & 4.00 & 6.00 & 0.67 \\
\hline 60 & 628.00 & 35.00 & 28.10 & 0.9026 & 31.59 & & 15.48 & 9.79 & & 2.21 & 3.48 & 0.63 \\
\hline 65 & 674.00 & 33.00 & 29.90 & 0.9049 & 29.86 & & 14.63 & 9.26 & & 2.09 & 3.28 & 0.60 \\
\hline 70 & 716.00 & 31.00 & 31.50 & 0.9061 & 28.09 & & 13.76 & 8.71 & & 1.97 & 3.09 & 0.56 \\
\hline 75 & 753.00 & 30.00 & 33.10 & 0.9073 & 27.22 & & 4.63 & 7.89 & 10.62 & 1.36 & 1.91 & 0.82 \\
\hline 80 & 785.00 & 29.00 & 34.70 & 0.9084 & 26.34 & & 4.48 & 7.64 & 10.27 & 1.32 & 1.84 & 0.79 \\
\hline 85 & 821.00 & 28.00 & 36.10 & 0.9091 & 25.45 & & 4.33 & 7.38 & 9.93 & 1.27 & 1.78 & 0.76 \\
\hline 90 & 847.00 & 28.00 & 37.60 & 0.9098 & 25.47 & & 3.82 & 5.60 & 12.74 & 1.27 & 1.27 & 0.76 \\
\hline 95 & 879.00 & 27.00 & 39.00 & 0.9108 & 24.59 & & 3.69 & 5.41 & 12.30 & 1.23 & 1.23 & 0.74 \\
\hline 100 & 900.00 & 28.00 & 40.40 & 0.9118 & 25.53 & & 3.83 & 5.62 & 12.77 & 1.28 & 1.28 & 0.77 \\
\hline $\begin{array}{c}\text { Major } \\
\text { harvest }\end{array}$ & 900.00 & 900.00 & 40.40 & 0.9118 & 820.62 & & 123.09 & 180.54 & 410.31 & 41.03 & 41.03 & 24.62 \\
\hline \multicolumn{2}{|c|}{ TOTAL } & $1,287.00$ & - & - & $1,317.64$ & 2.21 & 270.55 & 247.84 & 478.92 & 121.73 & 160.55 & 35.81 \\
\hline
\end{tabular}

Note: *Values from the MGT [3]; **Bark deduction was interpolated so that it responds the best to the $\mathrm{d}_{1.3}$ (diameter at breast height) [17]. 


\title{
Abstract
}

\section{FINANCIAL IMPACT IN CASE OF INVESTMENT TO THE FOREST PROPERTY AS A RESULT OF DIFFERENT TREE SPECIES COMPOSITION IN THE CZECH REPUBLIC}

\author{
Pavlína Köhler, Vlastimil Vala
}

The spruce covers the largest area $44.7 \%$ in the Czech Republic, but its natural representation was $11.2 \%$. Forest owners and managers are motivated to change their species composition. But the change will have an economic impact on their property. The aim of this research is to create a model of dependency of total profit from forest stand depending on its composition and prove that if the species composition is changed in favour of beech, the financial impact will be significantly negative. The model has area 100 ha with 100 forest groups which differ in age of one year. All the silviculture and logging activities were done within one year for eleven site indexes. Total volume of cuts was used from the Mensuration and Growth Tables. Prices of contractors including their profit margin and wood price from the Czech statistical office were used for revenues and costs calculations related to the roadside. The profit from the pure spruce stand is higher than profit from pure beech stand. The costs for establishing plantation did not differ in absolute values so much. The difference between revenues is caused mostly by different price for species assortments according to their quality. The profitability of potential investment, which presents costs to the pure spruce stands with the highest site index +1 (36) is $234 \%$, whereas profitability of beech stand in the same site index is only $151 \%$. Profit is a linear function of changing species composition. The localities with the lowest site index was it the red.

Key Words: Profit, spruce, beech, profitability, cost, revenues.

JEL Classification: C20, Q23, L73.

DOI: 10.15240/tul/001/2014-4-006 